\title{
A Paradigm Shift to Study Yoga: Holistic versus Reductionistic
}

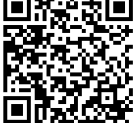

\author{
Grace Tsai Tsuyuki* \\ National Taiwan University, Taiwan
}

Submission: August 27, 2019; Published: September 09, 2019

*Corresponding author: Grace Tsai Tsuyuki, National Taiwan University, Taiwan

Keywords: Reductionism; Holism; Quantitative; Qualitative; Synergy; Intuitive; Changing Paradigms

\section{Opinion}

In the Structure of Scientific Revolutions, Thomas Kuhn argued that "paradigm shifts" arise when new evidence is set forth to challenge an existing system, facilitating the adoption of a new model [1]. In a 2015 retrospective on Kuhn, the philosopher Martin Cohen describes the notion of the paradigm shift as a kind of intellectual virus - spreading from hard science to social science and on to the arts and even everyday political rhetoric. Cohen [2] claims that Kuhn [1] had only a very hazy idea of what that might signify and accuses him of retreating from the more radical implications of his theory - that scientific facts are never really more than opinions, of transitory popularity and far from conclusive [2]. In this context, I propose that the study of "yoga science" would benefit from a paradigm shift from a reductionistic mindset to a holistic one (Figure 1). In the natural sciences, the predominant tendency over the past 75 years has been to give credence to only quantitative outcomes wherein numbers and equations were the only "true" measures of "sound" conclusions. "Qualitative outcomes were pushed to the back burner where personal thoughts, anecdotal evidence, and group experiences were dismissed as subjective, and therefore, not valid.

Reductionism
Parts
Structured
Rational
Prove it!
Hierarchy
Categories
Seperate
Future/past
Precise
Static
Male
Nosy
Seperate notes
Mechanic

Holism
Whole
Creative
Intuitive
Open mind
Synergy
Individuals
Connected
Now
Chaotic
Dynamic
Female
Selfcorrecting
Harmony
Organic

Figure 1: Paul Austin Murphy: A reductionist analysis of reductionism.
Marko Vojinovic Underscores My Point

Vojinovic notes, "I would like to raise a friendly criticism regarding the proponents of reductionism in Nature. The conclusions of this essay stand in sharp contrast to the popular opinion amongscientifically oriented people(evensomepracticing scientists) that reductionism unquestionably holdsin science. The reason for this popularity arguably lies mostly in the scientists' 
ignorance of the full axiomatic structure of the theories they study, and the lack of education in mathematical logic, especially its less trivial aspects. Despite being popular, the reductionist opinion is actually a heavy metaphysical assumption, virtually indefensible both on epistemological and ontological grounds. While reductionism can indeed be established in certain particular cases (which is always a useful thing to know), a sizable number of scientifically-oriented people generalize reductionism from these special cases to the full-blown level of scientific tautology (or something to that effect), completely disregarding a glaring lack of evidence and consistency [3]."

In the study of yoga - which I argue is the study of self - the reductionistic viewpoint only takes one so far. Yes, an "insight" gleaned from asana or pranayama practice can yield benefits but taken out of the context of a person's family, community and social network, this information may be quite limited. Thus, studying yoga within the current paradigm of male-oriented, left-brain, quantifiable results limits the actual benefits of sincerely following the yoga practice. Within the current social context, the \#MeToo movement in the U.S., illustrates a growing discontent with ignoring the feminine, yin components of the body/mind - an anger that is building even within the scientific community, heralding a paradigm shift that is underway. The light shed on Rosalind Franklin's contribution to the discovery of the structure of DNA, though initial credit went only to Watson and Crick, is evidence of this shift.

\section{As Nischala Joy Devi noted in The Secret Power of Yoga}

"The word sutra is related to the English word, 'suture,' a thread that strings or sews things together. The Yoga Sutras weave together the warp and weft of our material and spiritual lives, creating an inspiring tapestry. What many of us find lacking in the Yoga Sutras lies in their translations, written by and for male scholars from a left-brained, analytical perspective, often obliterating the wisdom they attempt to convey. It is my hope with this book to provide a unique commentary on the Yoga Sutras that emanates from the heart-an intuitive, feminine approach.... Since for a long-time woman were not highly regarded in a spiritual sense, the absence of emotionally centered parables, examples, and heart-centred teaching can be understood. The hundreds of commentaries and translations of the sutras written by men only further the exclusion in the spiritual world. Studies have shown that when the pronouns "he" or "him" are written or spoken, people do not make the leap of recognition that this also includes "she" and "her." This is why we see a movement in contemporary writing toward alternating "she" and "he," and in some cases, using s/he [4]."

We need to give credence to life experiences and a diversity of voices in order to further the study of yoga in differing contexts. Focus groups and ethnographic analyses of qualitative data can generate a deeper level understanding of how yoga is affecting practitioners across the globe. A holistic, heartcentered approach does not require a total disregard for the reductionistic, evidenced-based approach. Simply put, a paradigm shift is needed to open a new perspective where BOTH viewpoints can co-exist. Reliance on predominantly quantitative outcomes with numbers and graphs show little regard for the synergy of how specific components come together to create something entirely different. A more holistic research paradigm is long overdue. The study of yoga is the study of the self: the whole self, male or female, in its entirety.

\section{References}

1. Kuhn Thomas (1962) The Structure of Scientific Revolutions.

2. Cohen Martin (2015) Paradigm Shift: How Expert Opinions Keep Changing on Life, the Universe and Everything. Imprint Academic.

3. Marko Vojinovic (2015) Reductionism, emergence, and burden of proof - part II.

\begin{tabular}{l} 
Your next submission with Juniper Publishers \\
will reach you the below assets \\
- Quality Editorial service \\
- Swift Peer Review \\
- Reprints availability \\
- E-prints Service \\
- Manuscript Podcast for convenient understanding \\
- Global attainment for your research \\
- Manuscript accessibility in different formats \\
( Pdf, E-pub, Full Text, Audio) \\
- Unceasing customer service \\
Track the below URL for one-step submission \\
https://juniperpublishers.com/online-submission.php \\
\hline
\end{tabular}

